\title{
Review
}

\section{The privatization of hope: Ernst Bloch and the future of Utopia}

\author{
Peter Thompson and Slavoj Žižek \\ Duke University Press, Durham and London, 2013, ISBN: 978-0822355892 \\ Contemporary Political Theory (2015) 14, e18-e21. doi:10.1057/cpt.2014.61; \\ published online 20 January 2015
}

\section{History says, Don't hope \\ On this side of the grave. \\ But then, once in a lifetime \\ The longed-for tidal wave \\ Of justice can rise up}

And hope and history rhyme. (Heaney, 1990, pp. 77-78).

If Bloch is indeed 'our contemporary', as Žižek affirms in his typically lively Preface, this is because he is, from within his nevertheless expansive utopianism, witness to the manifest failure of hope, time and again and despite its persistence and ubiquity, to attain that which it promises: the revolutionary satisfaction of hunger, redemption, justice and joy - Heimat. Indeed, the ostensible starting point of this book picks up from where Bloch left off. In 1964, in conversation with uneasy ally Adorno, Bloch identifies a 'terrible banalization' of utopia. Adorno concurs, adding that 'utopian consciousness' has suffered a 'strange shrinking' to the extent that 'people are sworn to this world as it is, and have this blocked consciousness vis-à-vis possibility (Bloch and Adorno, 1988, pp. 3-4). The problem is not that humanity has lost its capacity to hunger and hope - there is, as Kafka laments, 'plenty of hope, an infinite amount of hope, but not for us' (Benjamin, 1999, p. 166; and referred to by Daly in this volume, p. 195). The crisis of hope is that, contra Seamus Heaney's insurgent rhyming, hope and history have unravelled, that hope has lost its utopian dynamic shaping social, collective and historical agency, becoming, instead, individualized, apolitical precisely privatized. This remains, nevertheless, an oddly titled book. Conceived during capitalism's period of triumphal hegemony, but birthed in the context of the 'Second Great Crash' (p. 1), the question of hope's 'privatization' is asserted but not directly confronted; indeed, it is belied by this rich collection of engaged essays.

The collection opens by considering Bloch's ontology of 'not-yet-being', rehearsed with Žižekian speed in his Preface. For Bloch, reality itself remains ontologically incomplete (a claim that Žižek finds echoed in Heisenberg and Bohr's 
quantum mechanics and that also resonates with the Derridean notion, implicit if not stated here, of spectrality). If reality itself remains open and unfinished, composed of competing strands of possibility or potentiality (the new, which is not yet birthed, as well as the past which is not yet dead), then utopian hope, as a principle, is, as Thomson argues in his Introduction, 'something linked not just to optimism but to the tendencies present in a material world that is constantly in flux' (p. 3). The central themes of Bloch's extraordinary body of work are explored through the lens provided by his 'speculative materialism': a materialism that is rendered dynamic by the 'notyet', by forms of potentiality that are ontologically latent in even the most closed, least hopeful, political present. Contributions by Wayne Hudson, Johan Seibers, Catherine Moir and Peter Thompson variously tackle the question of how the matter of materialism can be conceptualized when it contains 'not-yets': in what, asks Thompson, does a 'materialist understanding of an as yet non-existent future' consist? (p. 83). For Hudson, as for Moir, spaces of 'not-yet' enable the retheorization of hope, as 'an element of rationality' for Hudson (p. 24) and as docta spes (educated hope) for Moir, that is, as an affect that is also part of human agency, that 'grasps the latent tendency of the objectively real possible' (p. 137). As for the matter of the future, so too the matter of humanity itself, as Seibers illustrates, exploring 'humanity ... as a concept of utopian dimensions ... a fundamental openness to an identity that is not yet graspable ...' (p. 76). Situating Bloch in analytic or Kantian philosophical traditions, as these contributions do, does not domesticate Bloch; rather, it challenges, expands and refigures the limits of that tradition.

More darkly, an apocalyptic thread also runs through the book ("it is easier to imagine the end of the world than it is to imagine the end of capitalism' (p. 3)). Questioning the human domination of nature in all its guises (including Bloch's own anthropocentrism), Vincent Geoghegan's contribution imagines the possibility of utopias sans humans, countering 'misanthropic utopias of extinction' with antihumanist utopias that explore 'the humaneness of the anti-human' as a space which 'lifts humanity out of itself' (p. 57). And here we find a Blochian hermeneutic emerge, for even in the least prepossessing material Bloch perceived a utopian 'surplus': whether in the apocalyptical end of humanity, or in the religious narratives of insurrection, rebellion, domination and oppression that are central to Roland Boer's contribution, 'the most repressive myth has an emancipatory and utopian dimension ... an element that opens up other possibilities just when one has given up hope' (p. 110). David Miller turns this idea of a 'surplus' back on Bloch's Principle of Hope itself (a utopian hermeneutic fit for a utopian text) and looks, reflexively, at how we readers approach Bloch. Treating Bloch as 'allegorist' reinterprets the experience of difficulty (Bloch is hard!) as a political, not aesthetic, problem: Bloch's 'readability' is, to an extent, an index of our alienated state. But other sites reveal unalienated pockets of utopia in the here-and-now, tantalisingly explored by Ruth Levitas's contribution on music, a privileged site of utopian affect for Bloch: 'there is something in the nature of music itself and our making of it that reforms us as 
subjects and agents, and thus it conjures the possibility of a new world and moves us toward it' (p. 240). Even as music is situated, conditioned by its historically and geographically specific modes of production and reproduction, and involved in relations of domination and oppression ('the softest means of moulding the people's body according to the masters' will', Bloch, cited by Levitas, p. 231), it is an irreducible site of utopian affect and agency. Considering less likely, and even unlikely sites of utopianism is, nevertheless, just as illuminating for the utopist. Alongside Geoghegan's endeavour, consider Daly's worthy, if dense, attempt to locate hope in 'zero-points' of darkness and death where fear is more commonly presumed to be the dominant affective form; as Daly notes, though, fear has its own hopeful dynamic insofar as it 'creates longing and yearning' (p. 195). Rainer E. Zimmerman explores cyberspace and virtual worlds, and Francesca Vidal and Welf Schröter view demands for meaningful work, as diverse sites of utopianism, approached as a repository of everyday daydreams, hopes, wishes and desires that resonate with educative or political effect, as so much sustenance for the agential magic of docta spes. Caitríona Ní Dhúill also addresses the problematic of critical agency - whose agency, and how is that agency mobilized - by way of redressing something of a Blochian blind-spot: gender. She brings Bloch into dialogue with gender theory, tracing points of contiguity in the relationship each traces between hope, the present and future, emphasizing, in Butlerian vein, the disruptive and transformative moments implicit in social reproduction ('exact reproduction whether of bodies, values or behaviours - is impossible' (p. 145)). In this context, Henk de Berg's Fukuyamian wager - that the more ideal endeavour might very well be to stop being utopian, or to unlearn hope - sits awkwardly in the collection as a whole: as Kafka reminds us, there's a ubiquity about hope, and unlearning that might very well be to unlearn being human (if Bloch is right, it's ontologically impossible anyway).

What (as Bloch persisted in asking) is missing? While a number of essays consider Bloch's work in the context of an emerging field of speculative materialism, and Ní Dhúill engages with gender theories in dialogue with Marxism, post-structuralism, and the like, there's not much further consideration of other philosophical or theoretical contexts in which Bloch's work resonates. He certainly is unwieldy to discuss in Kantian terms, and his challenge to analytic philosophy is crucial, but what about those bodies of thought that begin with the disruptive, to which Bloch's style is most conducive, such as post-structuralism and affect theory, both politically engaged, potentially utopian, trajectories? Similarly, the question of political agency remains under-theorized. Just as the question of in what, precisely, does the privatization of hope consist is asserted rather than investigated, so, too, the question of how hope is mobilized as a politics is only obliquely addressed. Politically, for Bloch (1986), hope does not generate sanguine confidence: 'hope ... stands too close to the indeterminacy of the historical process, of the world process that, indeed, has not yet been defeated, but likewise has not yet won' (pp. 340-341). Instead, Bloch 
foregrounds the contingency and decisiveness of political struggles in the encounter with the emergent future, the 'Front' of the world, and political reflection on where those future-bearing struggles are to be found would have thoroughly undermined the already wobbly ostensible premise of the book, that hope has somehow been individuated and utopian consciousness has 'shrunk'. That said, this is a valuable collection of essays. Those of us engaged in utopian problematics are already inspired by Bloch's presence in the fields of literature and cultural studies; this collection goes some way towards establishing his presence similarly in the field of politics, political theory and philosophy.

\section{References}

Benjamin, W. (1999) Illuminations, Translated by. H. Zorn. London: Pimlico.

Bloch, E. (1986) 'Can Hope Be Disappointed?' Literary Essays, Translated by. A. Joron. California: Stanford University Press.

Bloch, E. and Adorno, T. (1988) Something's missing: A discussion between Ernst Bloch and Theodor Adorno on the contradictions of Utopian longing (1964). In: J. Zipes and F. Mecklenburg (eds.) The Utopian Function of Art and Literature: Selected Essays. Cambridge, MA: The MIT Press.

Heaney, S. (1990) The Cure at Troy: A Version of Sophocles's Philoctetes. London: Faber and Faber.

Susan McManus

Queen's University, Belfast, Belfast BT7 1NN, UK 